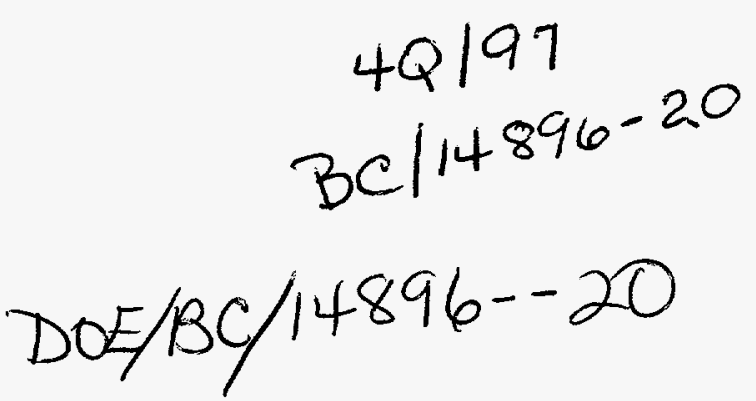

\title{
GEOLOGICAL AND PETROPHYSICAL CHARACTERIZATION OF THE FERRON SANDSTONE FOR 3-D SIMULATION OF A FLUVIAL-DELTAIC RESERVOIR
}

(Contract No. DE-AC22-93BC14896)

Utah Geological Survey (UGS), Salt Lake City, Utah 84114

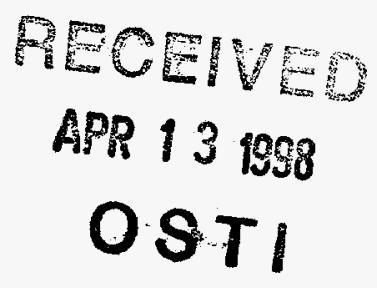

Submitted: January 1998

Contract Date: September 29, 1993

Anticipated Completion Date: April 30, 1998

Government Award (fiscal year): $\$ 32,025$

Principal Investigator: M. Lee Allison, UGS

Program Manager: Thomas C. Chidsey, Jr., UGS

Contracting Officer's Representative: Robert Lemmon, National Petroleum Technology Office, Tulsa, Oklahoma

Reporting Period: October 1 - December 31, 1997

\section{Objective}

The objective of this project is to develop a comprehensive, interdisciplinary, and quantitative characterization of a fluvial-deltaic reservoir which will allow realistic inter-well and reservoir-scale modeling to be constructed for improved oil-field development in similar reservoirs world-wide. The geological and petrophysical properties of the Cretaceous Ferron Sandstone in east-central Utah will be quantitatively determined. Both new and existing data will be integrated into a three-dimensional representation of spatial variations in porosity, storativity, and tensorial rock permeability at a scale appropriate for inter-well to regional-scale reservoir simulation. Results could improve reservoir management through proper infill and extension drilling strategies, reduction of economic risks, increased recovery from existing oil fields, and more reliable reserve calculations. Transfer of the project results to the petroleum industry is an integral component of the project.

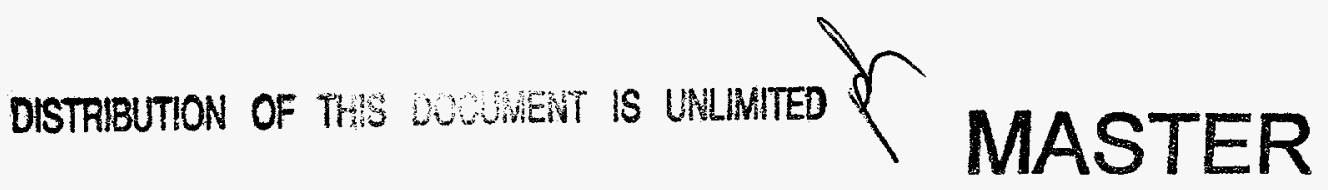




\section{DISCLAIMER}

This report was prepared as an account of work sponsored by an agency of the United States Government. Neither the United States Government nor any agency thereof, nor any of their employees, makes any warranty, express or implied, or assumes any legal liability or responsibility for the accuracy, completeness, or usefulness of any information, apparatus, product, or process disclosed, or represents that its use would not infringe privately owned rights. Reference herein to any specific commercial product, process, or service by trade name, trademark, manufacturer, or otherwise does not necessarily constitute or imply its endorsement, recommendation, or favoring by the United States Government or any agency thereof. The views and opinions of authors expressed herein do not necessarily state or reflect those of the United States Government or any agency thereof. 


\section{DISCLAIMER}

Portions of this document may be illegible electronic image products. Images are produced from the best available original document. 


\section{Summary of Technical Progress}

Two activities continued this quarter as part of the geological and petrophysical characterization of the fluvial-deltaic Ferron Sandstone: (1) regional stratigraphic interpretation and (2) technology transfer.

\section{Regional Stratigraphic Interpretation}

The Utah Geological Survey (UGS) continued to interpret photomosaics of the Ferron Sandstone outcrop belt (Fig. 1). Photomosaic interpretation uses observations from the 1994 and 1995 field seasons. Each photomosaic is being annotated with the following: flooding surfaces (transgressive surfaces of erosion), possible parasequence boundaries (surfaces which may be a flooding surface, but for which there is not clear evidence of transgression), base of channels, depositional tops of shoreline and bay-fill units, significant bedding surfaces of shoreline units, lateral accretion in tidal inlet and fluvial channel deposits, and bedding surfaces in slump features. ${ }^{1}$ A scale bar is included on the photomosaics based on the measurements made in the field on location points which are visible in the photographs. Field-based topographic-map tie points are also included as well as match points for adjacent photomosaics.

When completed, these photomosaics will be used for correlation, for development of cross sections, and for placement of the case-study areas into the regional setting. ${ }^{2}$ The annotated photomosaics will be available on compact discs to researchers.

\section{Technology Transfer}

\section{Geological Society of America Field Trip}

The UGS presented results of the Ferron project to both academia and industry on a field trip sponsored by the Geological Society of America (GSA) as part of their 1997 annual convention. The main Ferron Sandstone cliffs and its deeply incised canyons together provide a three-dimensional view of facies variations and transitions. The Ferron Sandstone has excellent exposures along depositional strike; numerous canyons that cut perpendicular to strike offer excellent exposures along the depositional dip direction.

The two-day field trip had two goals: (1) a review of regional stratigraphy and (2) detailed analysis of depositional environments and permeability trends. The first goal was to provide a detailed interpretation of the regional stratigraphy of the Ferron Sandstone outcrop belt from Dry Wash to Last Chance Creek (Fig. 1, stops 1 through 4, and stop 6) and explain how the regional morphological framework can be incorporated into model simulations at the oil and gas field scale. The dimensions and depositional environments of selected parasequence sets and the nature of the contacts between parasequences and facies were well displayed at various stops. The 15 field trip participants observed landward pinchouts of the marine facies enclosed within the coastal-plain facies. As the presentation developed, the participants saw how in the Ferron deltaic deposits, parasequence sets/stratigraphic units may be considered as large-scale reservoir blocks because marine and/or delta-plain shales that separate stratigraphic units may act as laterally extensive permeability barriers. Participants were also shown why the bounding surfaces (fluid-flow barriers or baffles), geometries, and depositional environments of these rocks make the Ferron Sandstone a world-class analog for fluvial-dominated deltaic oil and gas reservoirs. 
The second goal was to develop a detailed sedimentological characterization of the facies in the Ivie Creek case-study area just north of Interstate 70 (I-70) (Fig. 1, stop 5). The Ivie Creek casestudy area was selected because it contains abrupt facies changes in Kf- 1 and $\mathrm{Kf}-2$ parasequence sets. $\mathrm{Kf}-1$ is represented by a fluvial-dominated delta deposit consisting of two stacked parasequences preliminarily identified as Kf-1-Ivie Creek-a and Kf-1-Ivie Creek-c (Kf-1-Iv-a and Kf-1-Iv-c). Kf-1-Iv-a changes from proximal to distal from east to west and was the focus of geologic and permeability characterization during the project. $\mathrm{Kf}-2$ set represents a wave-modified deltaic deposit consisting of lower, middle, and upper shoreface, foreshore, and mouth-bar environments of deposition. Facies of this type are common in deltaic reservoirs worldwide. Participants saw how how variations in facies influence both compartmentalization and permeability structure. The field trip participants examined the major reservoir types (mouth-bar complex, wavemodified and fluvial-dominated delta front, distributary channel, and tidal deposits) associated with the Ferron Sandstone.

The field trip road logs and Ferron interpretations were published in a two-volume GSA guidebook. ${ }^{3}$ Geological, physiographical, and cultural features along the field trip route are noted in the road log.

\section{Presentations and Publications}

Ferron team members made three coordinated presentations at the 1997 annual convention of the GSA, covering aspects of the Ferron Sandstone project from outcrop description to computer reservoir simulation. ${ }^{4-6}$ These presentations discussed: (1) detailed reservoir architecture and characterization, and (2) the impact of detailed two-and three-dimensional clinoform facies architecture on reservoir performance.

The UGS also released an open-file report correlating Ferron Sandstone reservoir type logs to lithofacies. These type logs may be used to interpret lithofacies in other fluvial-deltaic deposits.

\section{References}

1. T. C. Chidsey, Jr., Geological and Petrophysical Characterization of the Ferron Sandstone for 3-D Simulation of a Fluvial-Deltaic Reservoir, Annual Report, DOE Contract No. DEAC22-93BC14896, DOE/BC/14896-15, May 1997.

2. P. B. Anderson, T. A. Ryer, and T. C. Chidsey, Jr., Ferron Sandstone - Stratigraphy and Reservoir Analogs, East-Central Utah [abs.]: Amer. Assoc. of Petrol. Geol. Bull. 80 (6): 965 (1996).

3. P. B. Anderson, T. C. Chidsey, Jr., and T. A. Ryer, Fluvial-Deltaic Sedimentation and Stratigraphy of the Ferron Sandstone, in Mesozoic to Recent Geology of Utah, P. K. Link, and B. J. Kowallis (Eds.), Brigham Young University Geology Studies, 42 (11): 135-154 (1997).

4. Ann Mattson, M. A. Chan, S. H. Snelgrove, C. B. Forster, and P. B. Anderson, From Outcrop to Simulation in the Ferron Sandstone - 1) Detailed Architecture and Characterization of a Fluvial-Dominated Deltaic Reservoir Analog [abs.]: Geol. Soc. of Am. 
Absts. w/ Prog. 29 (6): A-464 (1997).

5. S. H. Snelgrove, C. B. Forster, Ann Mattson, and P. B. Anderson, From Outcrop to Simulation in the Ferron Sandstone - 2) Impact of Detailed 2-D Clinoform Architecture on Performance of a Fluvial-Dominated Deltaic-Front Reservoir [abs.]: Geol. Soc. of Am. Absts. w/ Prog. 29 (6): A-464 (1997).

6. S. J. Colarullo, C. B. Forster, Hongmei Huang, and Ann Mattson, From Outcrop to Simulation in the Ferron Sandstone - 3) Impact of 3-D Clinoform Facies Architecture on Performance of a Fluvial-Dominated Deltaic-Front Reservoir [abs.]: Geol. Soc. of Am. Absts. w/ Prog. 29 (6): A-465 (1997).

7. P. B. Anderson, T. C. Chidsey, Jr., and Kevin McClure, Ferron Sandstone Reservoir Type Logs and Lithofacies, Emery County, Utah, Utah Geological Survey Open-File Report 358, 1997. 


\section{FIGURE CAPTIONS}

Fig. 1. Location map showing: the portion of the Ferron Sandstone outcrop belt (shaded) used in the regional stratigraphic interpretation, and Geological Society of America annual meeting field trip stops. 


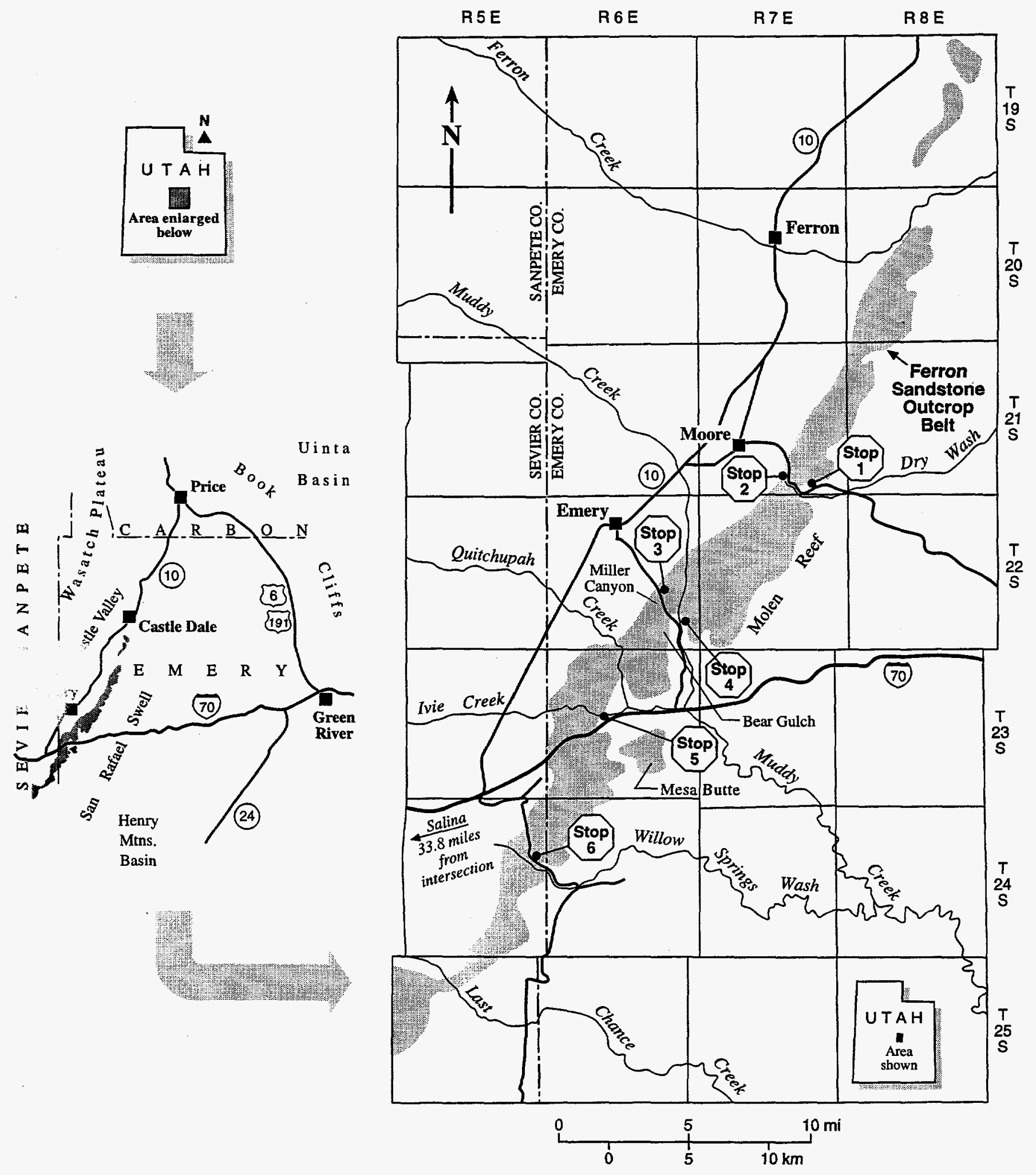

